\title{
STANDARDIZATION OF EFFECTIVE DOSE OF FOWL CHOLERA VACCINE IN PIGEON IN BANGLADESH
}

\author{
M. T. Islam ${ }^{1,2^{*}}$, M. H. Ali ${ }^{1,3}$, A. Chandra ${ }^{1,3}$, S. Saha ${ }^{1}$ and M. A. Islam ${ }^{1}$ \\ ${ }^{1}$ Department of Microbiology and Hygiene, Faculty of Veterinary Science, Bangladesh Agricultural University, \\ Mymensingh-2202, Bangladesh; ${ }^{2}$ Asssiant Commissioner, Ministry of Public Administration, People's Republic \\ of Bangladesh, Dhaka, Bangladesh; ${ }^{3}$ Department of Livestock Services, Ministry of Fisheries and Livestock, \\ People's Republic of Bangladesh, Dhaka, Bangladesh.
}

\begin{abstract}
An experiment was conducted to determine the effective dose of formalin killed (FK) fowl cholera (FC) vaccines prepared with virulent avian Pasteurella multocida (PM 38) serotype 1 (X-73) collected from the laboratory of the Department of Microbiology and Hygiene, BAU, Mymensingh. To determine the effective dose of vaccine, 7 weeks old 30 pigeons were immunized and each group consists of 5 birds. The groups are represented by A, B, C, D, E and F. The birds belonging to groups (A-E) were vaccinated with different doses of vaccine, after two weeks of first, second immunization and challenge experiment, blood was collected from all vaccinated birds, and serum was analyzed to determine antibody titer against $P$. multocida by passive hemagglutination test (PHA). The PHA titer after two weeks of first vaccination were $16 \pm 3.92$, $17.6 \pm 3.92,25.6 \pm 3.92,32 \pm 8.76,35.2 \pm 7.84$ of group A,B,C,D and E, respectively at the dose of $0.2 \mathrm{ml}\left(0.26 \times 10^{8} \mathrm{CFU}\right) / \mathrm{birds}$, $0.4 \mathrm{ml}\left(0.5 \times 10^{8} \mathrm{CFU}\right) /$ birds, $0.8 \mathrm{ml}\left(1.04 \times 10^{8} \mathrm{CFU}\right) / \mathrm{birds}, 1 \mathrm{ml}\left(1.3 \times 10^{8} \mathrm{CFU}\right) / \mathrm{birds}$, respectively. The PHA titer of prevaccination and control birds was $<4$. The PHA titer after 2 weeks of second vaccination or boostering were $32 \pm 8.76$, $35.2 \pm 7.84,44.8 \pm 7.84,57.6 \pm 18.66,70.4 \pm 15.68$, of group A,B,C,D and E, respectively. After 2 weeks of challenge infection, the mean PHA titer were $44.8 \pm 7.84,51.2 \pm 7.84,70.4 \pm 15.68,102.4 \pm 15.68$ and $140.8 \pm 31.34$ of group A,B,C,D and E, respectively. In this experiment, the antibody titer of the vaccinated pigeons with $0.4,0.6,0.8$ and $1 \mathrm{ml}$ per bird via intramuscular route were higher than that of the pigeons vaccinated with $0.4 \mathrm{ml} / \mathrm{bird}, 0.6 \mathrm{ml} / \mathrm{bird}, 0.8 \mathrm{ml} /$ bird and $1 \mathrm{ml} / \mathrm{bird}$ were satisfactory in terms of protective potential against $P$. multocida. For prevention and control of avian pasteurellosis $0.4 \mathrm{ml}$ to $0.6 \mathrm{ml}\left(0.52 \times 10^{8} \mathrm{CFU}\right.$ to $\left.0.78 \times 10^{8} \mathrm{CFU}\right) /$ birds of vaccine may be used instead of $1 \mathrm{ml}\left(1.3 \times 10^{8} \mathrm{CFU}\right) /$ birds for better immunization of pigeon against fowl cholera infection.
\end{abstract}

Keywords: Fowl cholera, pigeon, vaccine, dose

INTRODUCTION

Avian pasteurellosis (Fowl/duck cholera) is one of the most important infectious diseases of poultry, caused by Pasteurella multocida (P. multocida) Type A. It occurs sporadically and enzootically as per acute, acute and chronic from (Rimler and Glisson 1997). The disease primarily affects the adult birds including chicken, ducks, turkeys, pigeons and geese. This malady is encountered in most countries of the world including Bangladesh causing huge economic loss to the poultry raisers (Takai et al., 1994). The acute case of pasteurellosis is characterized by sudden death. The clinical signs appear as fever, diarrhea, anorexia, ruffled feathers, drowsiness, dyspnea, cyanosis and mucous discharge from mouth. The fecal materials remain initially watery and whitish color but later may become greenish and contain mucus (Gordon and Jordan, 1985).

In chronic case, the disease may either follow the acute case or due if the infection occurs with organism of lower virulence (Gordon and Jordan, 1985) characterized by local infections may appear. In such cases, the wattle, sinuses, conjunctiva, limb-joints, foot pads and sterna bursa often become swollen. Torticollis may be seen sometimes.

The high mortality of chicken from pasteurellosis has discouraged the poultry raisers to develop poultry industries and this is severely hampered by a number of outbreaks of fowl cholera. In Bangladesh, fowl cholera has been found as one of the most important endemics and devastating diseases occurring throughout the year and causing about 25 to $35 \%$ of total annual mortality of chickens (Choudhury et al., 1985).

*Corresponding e-mail address: tari.bau209@gmail.com

Copyright (c) 2017 Bangladesh Society for Veterinary Medicine

All rights reserved 0405/2017 


\section{T. Islam and others}

Pasteurella infection is transmitted by excretions from mouth, nose and conjunctiva of infected birds (Rimler and Glisson, 1997) and also may transmitted through carrier birds and insect vectors (Ivece, 1967).

To control any infectious diseases of animals and birds the programme vaccination has been universal safety measure. Promotion of profitable poultry industries has therefore been directed to prophylactic measures and this has gained a choice over curative efforts. In our country, the sustainability of poultry rising is interrelated with the adaption of potential success of the control of infectious diseases using vaccination. However, one of the leading requirements in this regard is to know the immunogenicity of antigens used for vaccination. It is imperative to look into the efficacy of vaccines through continuous surveillance and binding targets of concern for maximum efficacy.

In order to lower the incidence of fowl cholera one preventive measure is in the form of vaccination. The vaccines that are currently used the volume is $1 \mathrm{ml} /$ bird containing $1 \times 10^{8} \mathrm{CFU}$. The present study was therefore focused on dose reduction of vaccine which could be formulated to give protection inducing immune response against FC in Pigeon. Therefore, the present study has been undertaken to compare the different doses of vaccine and prevent economic losses from vaccination and to standardize an appropriate dose of vaccine effective against fowl cholera in pigeon.

\section{MATERIALS AND METHODS}

\section{Bacterial strain}

A stock culture of P. multocida (PM-38), serotype 1 (X-73) organism was obtained from the laboratory of Department of Microbiology and Hygiene, Bangladesh agricultural University, Mymensingh. The bacteria were originally isolated from a diseased duck from an outbreak of duck cholera (Choudhury et al., 1985).

\section{Experimental birds}

A total of 30 non-vaccinated healthy pigeons of seven weeks of age of local breed of either sex were obtained from some household of Trisal upazila of Mymensingh district and used for this experiment. The birds had no previous history of infection or vaccination against fowl cholera. Adequate balanced ration and water were given to the pigeons.

\section{Vaccine preparation}

$P$. multocida bacteria were cultured in nutrient broth enriched with yeast extract and incubated for overnight at $37^{\circ} \mathrm{C}$, shaken at $4-5 \mathrm{hrs}$ interval manually. It was stocked in $80 \%$ glycerol and CFU was counted. Formalin was added @8 $8 \mathrm{ml} / 1000 \mathrm{ml}$ and kept in room temperature for $24 \mathrm{hrs}$. Alum was added as adjuvant @35gm/1000ml and kept at room temperature. The sterility was tested on blood agar media and safety test was done in chicken and mice. Finally formalin killed fowl cholera vaccine was prepared.

\section{Experimental immunization}

Thirty birds of local breed were divided into six groups consisting of five birds in each group. The birds of group A, B, C, D and E were vaccinated subcutaneously (SC) with different set doses of experimentally prepared formalin killed fowl cholera vaccine. The initial doses of vaccine were given to the birds of groups A, B, C, D and $\mathrm{E}$ at the age of seven weeks. These birds were re-vaccinated with same doses of vaccine after two weeks of primary vaccination at the age of nine weeks. The birds of group F served as control.

Table 1. Vaccination schedule for the immunization of experimental pigeons with formalin killed vaccine

\begin{tabular}{cc}
\hline Group & Dose of vaccine \\
\hline eA & $0.2 \mathrm{ml}\left(0.26 \times 10^{8} \mathrm{CFU}\right)$ \\
B & $0.4 \mathrm{ml}\left(0.52 \times 10^{8} \mathrm{CFU}\right)$ \\
C & $0.6 \mathrm{ml}\left(0.78 \times 10^{8} \mathrm{CFU}\right)$ \\
D & $0.8 \mathrm{ml}\left(1.04 \times 10^{8} \mathrm{CFU}\right)$ \\
E & $1.0 \mathrm{ml}\left(1.3 \times 10^{8} \mathrm{CFU}\right)$ \\
\hline
\end{tabular}




\section{Collection of serum from the immunized birds}

$3 \mathrm{ml}$ of blood was collected either from the jugular vein or wing vein of all vaccinated pigeons of each group without anticoagulant and was poured gently in sterile glass tubes. The sera was collected in pre-vaccination (7 weeks of age), after first vaccination (at 9 weeks), after booster vaccination (11 weeks) and after challenge (13 weeks). The sera were collected according to the procedure of Tripathy et al. (1970).

\section{Passive hemagglutination assay (PHA)}

The test was performed to determine antibody titer of the vaccinated (primary, booster and challenge) pigeons according to the method described by Tripathy et al. (1970) with slight modification. The modification for the test is as follows:

\begin{tabular}{ccc}
\hline Reagents & Tripathy et al. (1970) & Present investigation \\
\hline PBS & $\mathrm{pH} 6.4$ & $\mathrm{pH} 7.2$ \\
Tannic acid solution & $1: 25,000$ & $1: 20,000$ \\
$\mathrm{Na}_{2} \mathrm{HPO}_{4} \cdot 12 \mathrm{H}_{2} \mathrm{O}$ & $0.15 \mathrm{M}$ & $0.2 \mathrm{M}$ \\
$\mathrm{KH}_{2} \mathrm{PO}_{2 \cdot} \mathrm{H}_{2} \mathrm{O}$ & $0.15 \mathrm{M}$ & $0.2 \mathrm{M}$ \\
\hline
\end{tabular}

\section{Collection and preservation of serum as complement from male guineapig}

Adult healthy male guineapig was obtained from the Department of Microbiology and Hygiene, BAU, Mymensingh. An amount of $10 \mathrm{ml}$ of blood was collected directly from the heart without using anticoagulant. Aseptically collected blood was immediately poured into a $100 \mathrm{ml}$ volume of conical flask previously kept on ice. As complement is labile even at room temperature, refrigeration temperature was strictly maintained in all the steps of preparation and preservation. The prepared serum of guinea pig was dispensed in small volume in sterile vials and preserved at $-20^{\circ} \mathrm{C}$ until used (Tripathy et al., 1970).

\section{Collection and preservation of sheep red blood cells (SRBC) suspension}

The collection and preservation of SRBE suspension and rabbit serum was done according to the procedure of Tripathy et al. (1970). Determination of the humoral immune response (HIR) of pigeons was performed according to Cheesbrough (1985).

\section{Statistical analysis}

The antibody titers of vaccinated and control pigeons were analyzed by Student $t$ test. The survivability percentage of the pigeons was analyzed by Mantel log rank test. P value of $<0.05$ was considered significant.

\section{RESULTS}

Clinical findings after challenge

All the experimentally vaccinated and control birds that were challenged with virulent strain of. $P$. multocida PM-38, serotype $1(\mathrm{X}-73)$ by intramuscular route at the dose of $1.4 \times 10^{7} \mathrm{CFU} / \mathrm{ml}$ manifested the following clinical changes:

\section{Control birds}

Non-vaccinated control birds showed no clinical signs at 3 hours of post inoculation (PI). The clinical signs first appeared at 6 hours PI-included dullness and depression. At 12 hours PI, there were dullness, depression, slight rise of body temperature $\left(42.5^{\circ} \mathrm{c}\right)$ and increased respiratory rate $(40-45 / \mathrm{min})$. The observed clinical signs at 24 hours PI were severe weakness, drowsiness, anorexia, rise of body temperature $\left(43.6^{\circ} \mathrm{c}\right)$, increased respiratory rate (45-55/min), lameness, whitish (chalky) diarrhoea with mucus. The clinical signs at 48 hours PI were almost similar to that or 24 hours.

The other signs included anorexia, lameness, greenish diarrhoea with mucus, subnormal temperature $\left(41^{\circ} \mathrm{C}\right)$, decreased respiratory rate $(15-25 / \mathrm{min})$. Death of one bird occurred first at 48 hours PI, one died at 72 hours and the rest died at 96 hours PI. 


\section{T. Islam and others}

The vaccinated pigeons did not exhibit any clinical signs and there was no death within 96 hours of PI. After 7 days of PI, in some birds of group A, although there was formation of cyst like structure at elbow joint of the legs, but after 30 days of PI the cysts got diminished.

\section{Results of the mean PHA titer of sera of vaccinated pigeons}

The mean PHA titer of sera of birds of groups A,B,C,D, and E were 16=4.29, 17.6 $\pm 3.92,25.6 \pm 3.92,32 \pm 8.76$ and $35.2 \pm 7.84$ respectively. After 2 weeks of booster vaccination, the sera of group A,B,C,D, and E revealed the mean PHA titer $32 \pm 8.76,35.2 \pm 7.84,44.8 \pm 7.84,57.6 \pm 18.66$ and $70.4 \pm 15.68$ respectively. After 2 weeks of challenge infection, the sera of group A, B, C, D and E revealed the mean PHA titer 44.8 $\pm 7.84,51.2 \pm 7.84,70.4 \pm 15.68,102.4 \pm 15.68$ and $140.8 \pm 31.34$ respectively. The mean PHA titers of Pigeons vaccinated with different doses were shown in Figure 1 . The comparison of serum mean PHA titer of pigeons vaccinated with different doses has shown in Figure 2. Figure 3 were showing the PHA test for the detection antibody titer after primary vaccination and figure 4 were showing the PHA test for the detection antibody titer after booster vaccination. Figure 5 were showing the PHA test for the detection antibody titer after challenge infection.

After 14 days of challenge exposure, a few of the selected survivors of each challenged group were sacrificed. From these birds, swab or tissue materials from liver, lungs, spleen, kidney, brain were streaked on the blood agar plates and incubated at $37^{\circ} \mathrm{C}$ for 24 to 48 hours. Then the plates were examined and observed for characteristic colonies of $P$. multocida.

\section{Survivability at challenge experiment}

All the vaccinated groups of birds of this experiment protected from challenge infection. Thus survivability rate of vaccinated chickens was $100 \%$

Table 2. Determination of pathogenicity of $P$. multocida in vaccinated and non vaccinated pigeons

\begin{tabular}{|c|c|c|c|c|c|c|c|c|c|c|c|c|c|c|c|c|c|c|c|}
\hline \multirow{2}{*}{$\begin{array}{l}\text { Kinds of } \\
\text { Vaccine }\end{array}$} & \multirow{2}{*}{$\begin{array}{c}\text { Groups } \\
\text { of } \\
\text { pigeons }\end{array}$} & \multirow{2}{*}{$\begin{array}{l}\text { Dose and Routes } \\
\text { of Vaccination }\end{array}$} & \multirow{2}{*}{$\begin{array}{l}\text { Route and Dose } \\
\text { Of Challenge }\end{array}$} & \multirow{2}{*}{$\begin{array}{c}\text { No. of } \\
\text { pigeons }\end{array}$} & \multicolumn{15}{|c|}{ Results of pathogenicity in pigeon after challenge } \\
\hline & & & & & \multicolumn{5}{|c|}{ Sick } & \multicolumn{5}{|c|}{ Dead } & \multicolumn{5}{|c|}{ Alive } \\
\hline \multirow{5}{*}{$\begin{array}{l}\text { Formalin } \\
\text { killed Fowl } \\
\text { Cholera } \\
\text { vaccine }\end{array}$} & $\mathrm{A}$ & $\begin{array}{c}\mathrm{IM}, 0.2 \mathrm{ml} \\
\left(0.26 \times 10^{8} \mathrm{CFU}\right) \\
\end{array}$ & $\begin{array}{c}\text { IM 1ml } \\
\left(1.4 \times 10^{7} \mathrm{CFU}\right) \\
\end{array}$ & 5 & $\begin{array}{l}14 \\
\mathrm{hr}\end{array}$ & $\begin{array}{l}24 \\
\mathrm{hr}\end{array}$ & $\begin{array}{l}48 \\
\mathrm{hr} \\
\end{array}$ & $\begin{array}{l}72 \\
\mathrm{hr}\end{array}$ & $\begin{array}{l}96 \\
\mathrm{hr}\end{array}$ & $\begin{array}{l}14 \\
\mathrm{hr}\end{array}$ & $\begin{array}{l}24 \\
\mathrm{hr}\end{array}$ & $\begin{array}{l}48 \\
\mathrm{hr}\end{array}$ & $\begin{array}{l}72 \\
\mathrm{hr}\end{array}$ & $\begin{array}{l}96 \\
\mathrm{hr}\end{array}$ & $\begin{array}{l}14 \\
\mathrm{hr}\end{array}$ & $\begin{array}{l}24 \\
\mathrm{hr}\end{array}$ & $\begin{array}{l}48 \\
\mathrm{hr} \\
\end{array}$ & $\begin{array}{l}72 \\
\mathrm{hr}\end{array}$ & $\begin{array}{l}96 \\
\mathrm{hr} \\
\end{array}$ \\
\hline & B & $\begin{array}{c}\mathrm{IM}, 0.4 \mathrm{ml} \\
\left(0.52 \times 10^{8} \mathrm{CFU}\right)\end{array}$ & $\begin{array}{c}\mathrm{IM} \mathrm{1 \textrm {ml }} \\
\left(1.4 \times 10^{7} \mathrm{CFU}\right)\end{array}$ & 5 & 0 & 0 & 0 & 0 & 0 & 0 & 0 & 0 & 0 & 0 & 5 & 5 & 5 & 5 & 5 \\
\hline & $\mathrm{C}$ & $\begin{array}{c}\mathrm{IM} .0 .6 \mathrm{ml} \\
\left(0.78 \times 10^{8} \mathrm{CFU}\right)\end{array}$ & $\begin{array}{c}\text { IM 1ml } \\
\left(1.4 \times 10^{7} \mathrm{CFU}\right) \\
\end{array}$ & 5 & 0 & 0 & 0 & 0 & 0 & 0 & 0 & 0 & 0 & 0 & 5 & 5 & 5 & 5 & 5 \\
\hline & $\mathrm{D}$ & $\begin{array}{c}\mathrm{IM}, 0.8 \mathrm{ml} \\
\left(1.04 \times 10^{8} \mathrm{CFU}\right) \\
\end{array}$ & $\begin{array}{c}\mathrm{IM} \mathrm{1ml} \\
\left(1.4 \times 10^{7} \mathrm{CFU}\right) \\
\end{array}$ & 5 & 0 & 0 & 0 & 0 & 0 & 0 & 0 & 0 & 0 & 0 & 5 & 5 & 5 & 5 & 5 \\
\hline & $\mathrm{E}$ & $\begin{array}{c}\mathrm{IM}, 1.0 \mathrm{ml} \\
\left(1.04 \times 10^{8} \mathrm{CFU}\right)\end{array}$ & $\begin{array}{c}\mathrm{IM} \mathrm{1 \textrm {ml }} \\
\left(1.4 \times 10^{7} \mathrm{CFU}\right) \\
\end{array}$ & 5 & 0 & 0 & 0 & 0 & 0 & 0 & 0 & 0 & 0 & 0 & 5 & 5 & 5 & 5 & 5 \\
\hline \multicolumn{3}{|c|}{ Control } & $\begin{array}{c}\mathrm{IM} \mathrm{1ml} \\
\left(1.4 \times 10^{7} \mathrm{CFU}\right)\end{array}$ & 5 & 5 & 5 & 4 & 3 & 0 & 0 & 0 & 1 & 1 & 3 & 5 & 5 & 4 & 3 & 0 \\
\hline
\end{tabular}

Table 3. Mean PHA titers with SE of sera of vaccinated and control pigeons

\begin{tabular}{|c|c|c|c|c|c|c|c|}
\hline \multirow[b]{2}{*}{$\begin{array}{l}\text { Type of } \\
\text { Vaccine }\end{array}$} & \multirow[b]{2}{*}{$\begin{array}{l}\text { Route and dose Of } \\
\text { vaccination }\end{array}$} & \multirow[b]{2}{*}{$\begin{array}{c}\text { Experimental } \\
\text { Groups }\end{array}$} & \multirow[b]{2}{*}{$\begin{array}{l}\text { No. Of } \\
\text { pigeons }\end{array}$} & \multirow{2}{*}{$\begin{array}{c}\text { Pre- } \\
\text { vaccination } \\
\text { PHA titer }\end{array}$} & \multicolumn{3}{|c|}{$\begin{array}{l}\text { Post-vaccination PHA titer of scrum (mean I'llA titer with } \\
\text { SE) }\end{array}$} \\
\hline & & & & & $\begin{array}{l}\text { After } 2 \text { weeks of } \\
\text { First vaccination }\end{array}$ & $\begin{array}{c}\text { After } 2 \text { weeks of } \\
\text { Booster } \\
\text { vaccination }\end{array}$ & $\begin{array}{l}\text { After } 2 \text { weeks of } \\
\text { Challenge Infection }\end{array}$ \\
\hline \multirow{6}{*}{$\begin{array}{l}\text { Formalin killed } \\
\text { Fowl Cholera } \\
\text { vaccine }\end{array}$} & $\begin{array}{c}\text { IM } 0.2 \mathrm{ml} \\
\left(0.26 \times 10^{8} \mathrm{CFU}\right)\end{array}$ & A & 5 & $\leq 4$ & $16 \pm 4.29 *$ & $32 \pm 8.76^{*}$ & $44.8 \pm 7.84 * *$ \\
\hline & $\begin{array}{c}\mathrm{IM} 0.4 \mathrm{ml} \\
\left(0.52 \times 10^{8} \mathrm{CFU}\right)\end{array}$ & B & 5 & $\leq 4$ & $17.6 \pm 3.92 *$ & $35.2 \pm 7.84 *$ & $51.2 \pm 7.84 * *$ \\
\hline & $\begin{array}{c}\mathrm{IM} 0.6 \mathrm{ml} \\
\left(0.78 \times 10^{8} \mathrm{CFU}\right)\end{array}$ & $\mathrm{C}$ & 5 & $\leq 4$ & $25.6 \pm 3.92 *$ & $44.8 \pm 7.84 *$ & $70.4 \pm 15.68 * *$ \\
\hline & $\begin{array}{c}\mathrm{IM} 0.8 \mathrm{ml} \\
\left(1.04 \times 10^{8} \mathrm{CFU}\right)\end{array}$ & D & 5 & $\leq 4$ & $32 \pm 8.76^{*}$ & $57.6 \pm 18.66^{*}$ & $102.4 \pm 15.68 * *$ \\
\hline & $\begin{array}{c}\mathrm{IM} 1 \mathrm{ml} \\
\left(1.3 \times 10^{8} \mathrm{CFU}\right)\end{array}$ & E & 5 & $\leq 4$ & $35.2 \pm 7.84 *$ & $70.4 \pm 15.68 *$ & $140.8 \pm 31.34 *$ \\
\hline & Control group & & 5 & $\leq 4$ & $\leq 4$ & $\leq 4$ & - \\
\hline
\end{tabular}


Standardization of effective dose of fowl cholera vaccine

Table 4. PHA titer of the sera of vaccinated and control pigeons

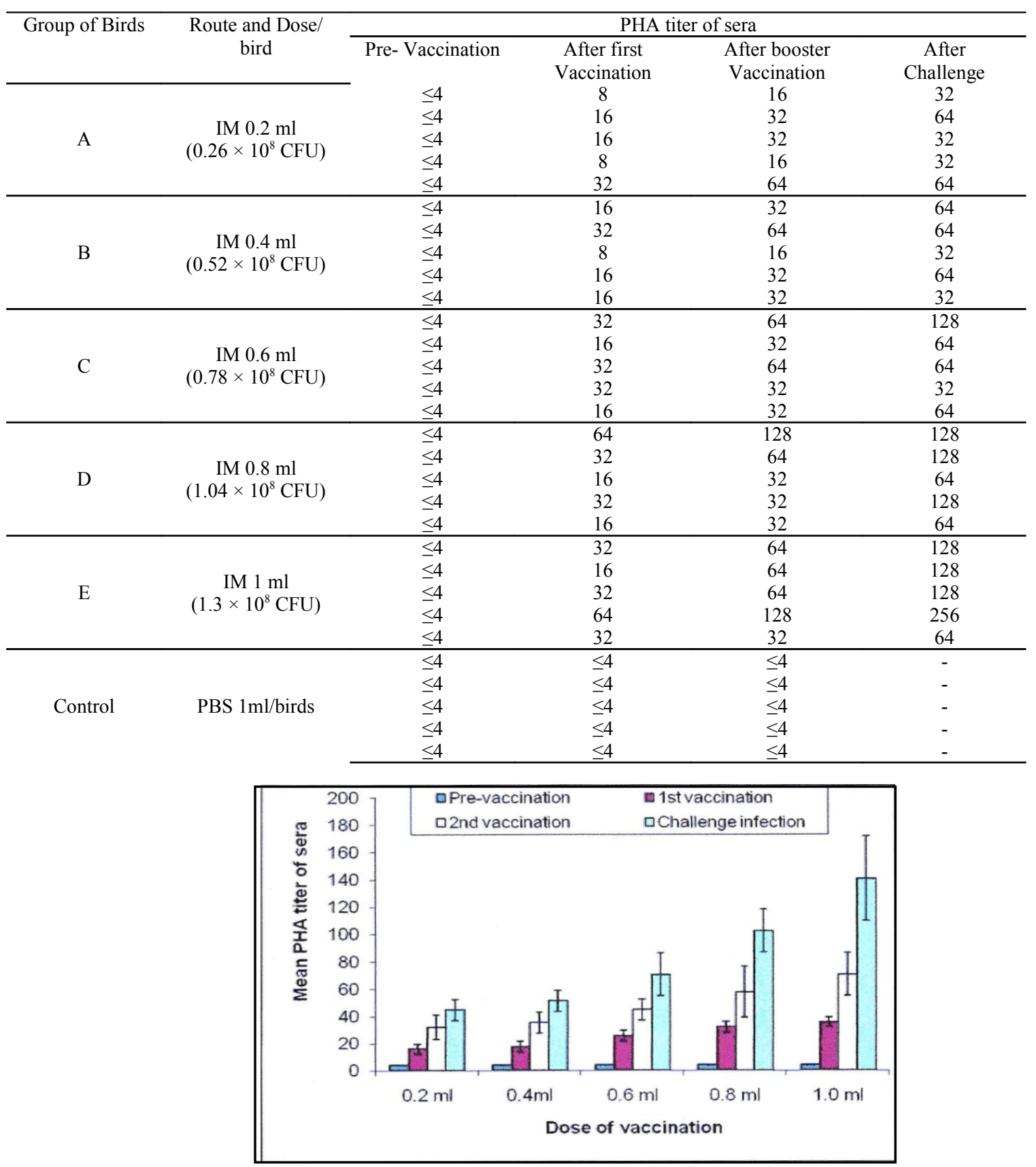

Figure 1. The histogram mean PHA titer of Pigeons vaccinated with different doses 


\section{T. Islam and others}

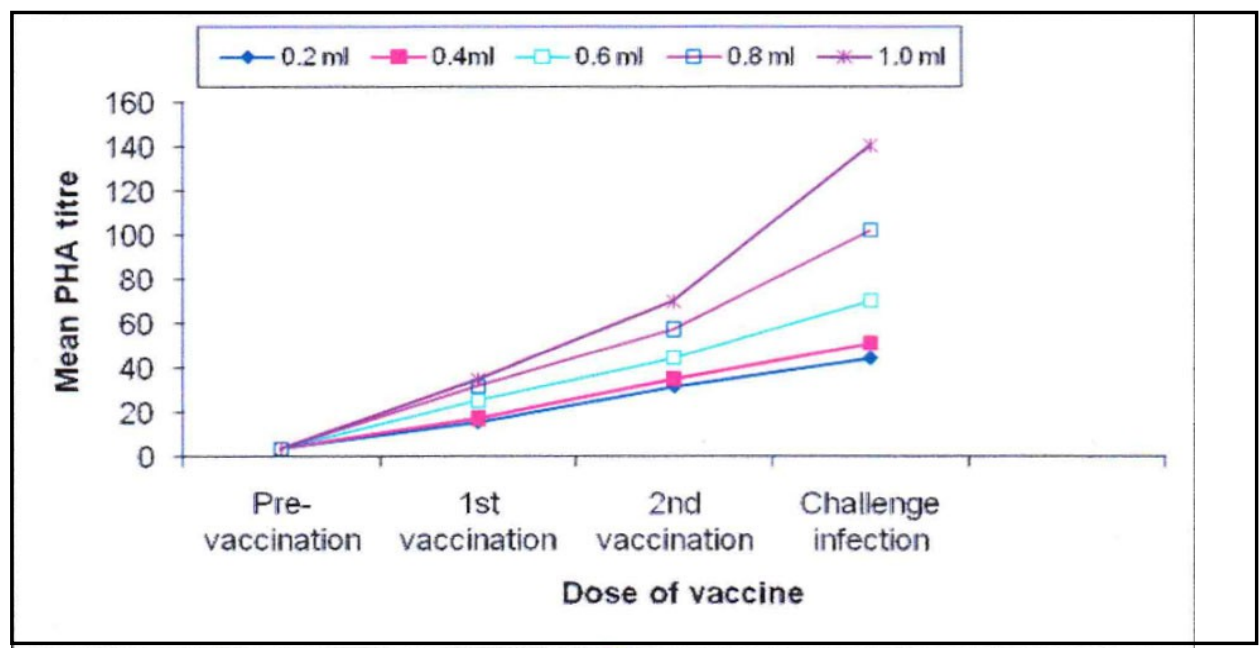

Figures 2. The graph of comparison of serum mean PHA titer of pigeons vaccinated with different doses

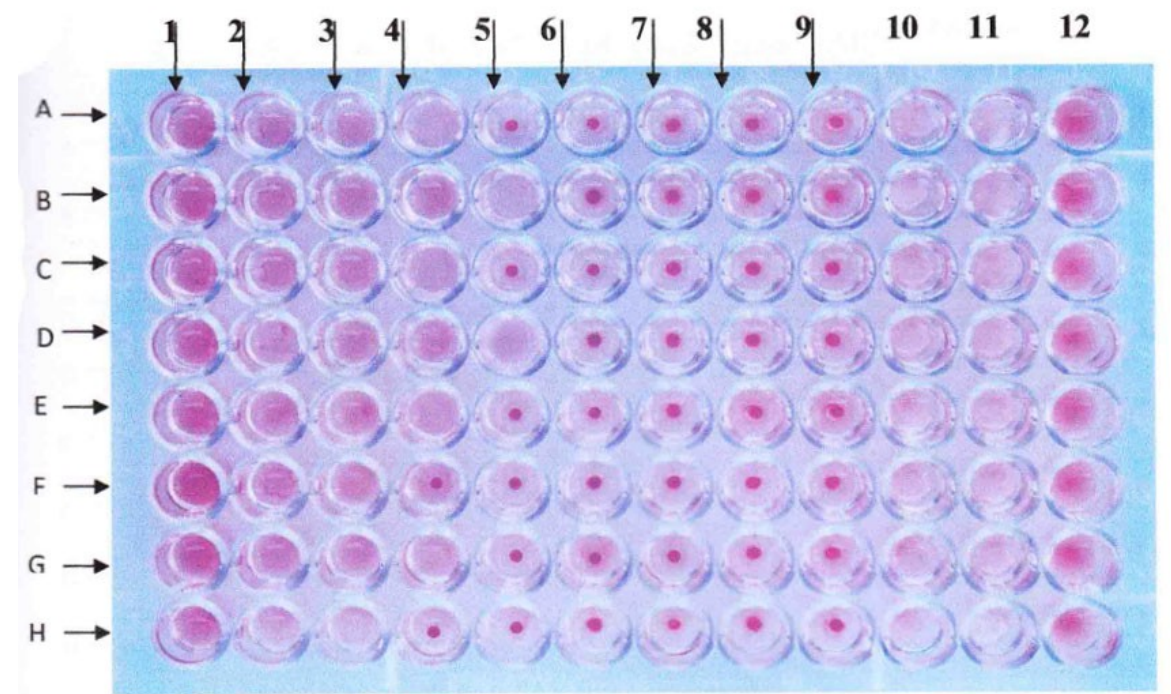

Legends

-10th well, content: equal volume of $50 \mu \mathrm{l}$ of sensitized SRBC and normal serum; 11 th well, content: equal volume of $50 \mu \mathrm{l}$ of sensitized SRBC and undiluted serum; 12th well, content: equal volume of $50 \mu 1$ of 1:10 dilution of partially purified capsular antigen suspension and PBS.

Figure 3. Showing the passive hemagglutination test for the detection antibody titer after primary vaccination where row A, B contain pigeon serum of group A; row C, D contain pigeon serum of group B; row E, F contain pigeon serum of group $\mathrm{C}$; row $\mathrm{G}, \mathrm{H}$ contain pigeon serum of group $\mathrm{D}$. 


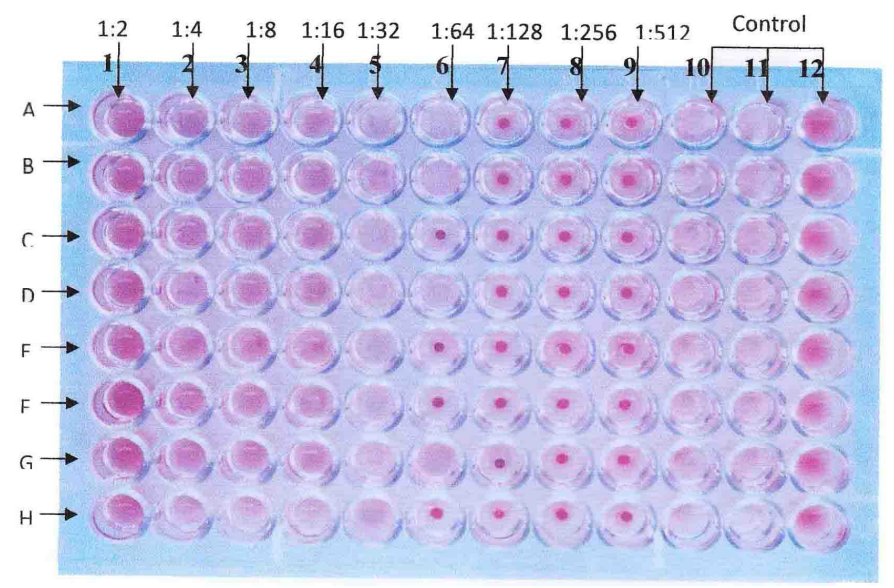

Legends

-10th well, content: equal volume of $50 \mu \mathrm{l}$ of sensitized SRBC and normal serum; 11th well, content: equal volume of $50 \mu \mathrm{l}$ of sensitized SRBC and undiluted serum; 12th well, content: equal volume of $50 \mu 1$ of 1:10 dilution of partially purified capsular antigen suspension and PBS.

Figure 4. Showing the passive hemagglutination test for the detection antibody titer after booster vaccination where row A, B contain pigeon serum of group A; row C, D contain pigeon serum of group B; row E, F contain pigeon serum of group $\mathrm{C}$; row $\mathrm{G}, \mathrm{H}$ contain pigeon serum of group $\mathrm{D}$.

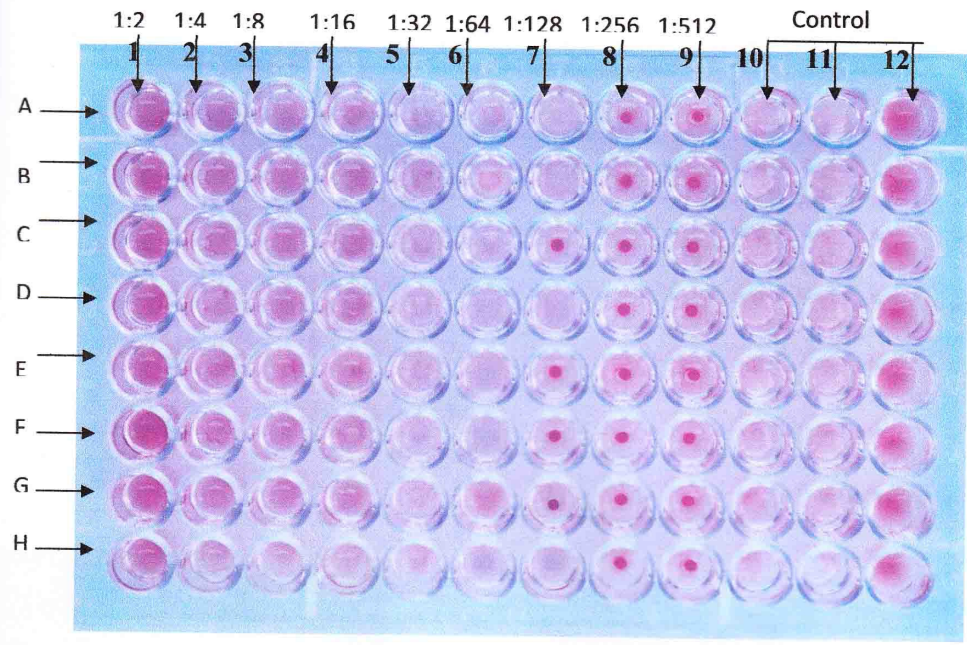

Legends

-10 th well, content: equal volume of $50 \mu \mathrm{l}$ of sensitized SRBC and normal serum; 11th well, content: equal volume of $50 \mu 1$ of sensitized SRBC and undiluted serum; 12th well, content: equal volume of $50 \mu 1$ of 1:10 dilution of partially purified capsular antigen suspension and PBS.

Figure 5. Showing the passive hemagglutination test for the detection antibody titer after challenge infection where row A, B contain pigeon serum of group A; row C, D contain pigeon serum of group B; row E, F contain pigeon serum of group $\mathrm{C}$; row $\mathrm{G}, \mathrm{H}$ contain pigeon serum of group $\mathrm{D}$. 


\section{T. Islam and others}

\section{DISCUSSION}

In all groups of vaccinated birds, the mean PHA titre after two weeks of booster vaccination showed higher than that of primary vaccination and after 2 weeks of challenge infection the mean PHA titre that recorded in this experiment was higher than that of booster vaccination. Choudhury et al. (1990) immunized chickens using formalin killed alum precipitated fowl cholera vaccine prepared with $P$. multocida (PM-3 8), serotype 1 (X-73) and administered twice at two weeks interval and observed that total serum protein and immunoglobulin levels increased in double vaccinated groups of birds. Schlink and Olson (1987) and Choudhury et al. (1987) observed that the administration of booster dose of same vaccine induced a high level of antibody and protective immunity with no adverse reaction. Onet et al. (1994) observed that the level of specific antibodies increased at least 3 times by twice vaccination.

In this experiment, the challenge dose used for protection test was $1.4 \times 10^{7} \mathrm{CFU} / \mathrm{ml} \mathrm{P.} \mathrm{multocida}$. The results of protection rate of pigeons of different vaccinated groups were found almost similar when challenge with virulent strain of P. multocida. In this experiment, after 7 days of challenge infection, 3 birds of group A that were vaccinated at the dose of $0.2 \mathrm{ml}\left(0.26 \times 10^{8} \mathrm{CFU}\right) /$ bird revealed tumor like structures formed at elbow joints of legs which were characteristics signs of chronic localized lesion of avian pasteurellosis. In this experiment, different groups of birds that received different dose of vaccine $(0.2$ to $1 \mathrm{ml}$ per birds $)$ protected $100 \%$ birds although Coates et al. (1977) observed that the turkeys receiving the light dose of oral vaccine produced very low levels of antibody and were virtually unprotected. However, turkeys receiving the high and medium doses responded with higher levels of antibody and were highly able to withstand large oral doses of virulent $P$. multocida.

In this experiment, the antibody titer of the vaccinated pigeons with $0.4,0.6,0.8$ and I ml per bird via intramuscular route were higher than that of the pigeons vaccinated with $0.2 \mathrm{ml} / \mathrm{bird}$. The immune responses of pigeons vaccinated with $0.4 \mathrm{ml} /$ bird, $0.6 \mathrm{ml} / \mathrm{bird}, 0.8 \mathrm{ml} /$ bird and $1 \mathrm{ml} /$ bird were satisfactory in terms of protection rate against $P$. multocida. For prevention and control of avian pasteurellosis $0.4 \mathrm{ml}$. to $0.6 \mathrm{ml}(0.52 \times$ $10^{8} \mathrm{CFU}$ to $\left.0.78 \times 10^{8} \mathrm{CFU}\right) /$ bird of vaccine may be used instead of $1 \mathrm{ml}\left(1.3 \times 10^{8} \mathrm{CFU} / \mathrm{bird}\right.$ for better immunization of pigeon. against fowl cholera infection. A further detail study with large number of birds will be essential to determine minimum 'effective dose of fowl cholera vaccine.

\section{CONCLUSIONS}

The results of protection test after challenge infection revealed that all the pigeons of group B, C, D and E vaccinated with $0.4 \mathrm{ml}, 0.6 \mathrm{ml}, 0.8 \mathrm{ml}$ and $1 \mathrm{ml} /$ bird respectively were well protected. Whereas, few pigeons of group A $(0.2 \mathrm{ml} /$ bird $)$ showed chronic type of localize infection after challenge. This protection test indicated that all doses of vaccine protected $100 \%$ vaccinated birds.

\section{REFERENCES}

1. Cheesbrough M (1985). Medical Laboratory manual for tropical Countries. Vol. II. Microbiology. $1^{\text {st }}$ edi. ELBS edit. UK. 28-32, 50-69.

2. Choudhury KA, Amin MM, Rahman A and Ali MR (1985). Investigation of natural outbreak of fowl cholera. Bangladesh Veterinary Journal 19: 49-56.

3. Choudhury KA, Amin MM, Sarker AJ, Ali MR and Ahmed AR (1987). Immunization of chickens against fowl cholera with oil adjuvanted broth culture vaccine. Bangladesh Veterinary Journal 21: 63-73.

4. Choudhury KA, Mondal SK, Rahman MM, Amin MM and Sarker AJ (1990). Changes in leukocytes, total serum protein and immunoglobulin levels in chicken immunized against fowl cholera. Bangladesh Veterinary Journal 7: 27-30.

5. Coates RS, Jensen JM and Brown ED (1977). The response of turkey to varying doses of live oral P. multocida Vaccine. Poultry Science 56: 273-276.

6. Gordon RE and Jordan FT (1985). Poultry diseases. $2^{\text {nd }}$ ed. ELBS. Baillier. Tindall, London, 44-46.

7. Ivece E (1967). The role of argas persicus in the epidemiology of Fowl Cholera. Angew Parasitology 8: 114-117. 
8. Onet EG, Collins NF and Richards S (1994). Observations on immunological response of turkeys vaccinated against fowl cholera. Studies and Researches in Veterinary Medicine 4: 97-101.

9. Rimler RB and Glisson JR (1997). Fowl Cholera. In: Diseases of Poultry, $10^{\text {th }}$ ed., Iowa State University Press, Ames, Iowa. 143-159.

10. Schlink GT and Olson LD (1987). Fowl cholera vaccination of growing turkeys with CU strain via routs other than oral. Avian Diseases 31: 22-28.

11. Takai H, Hayakawa Y, Shintani F, Komae H, Yoshida Y, Tde H, Abe G and Sawada T (1994). The first outbreak of Pasteurella multocida infection in turkeys in Japan. Journal of Japan Veterinary Medicine Association 47: 923 927.

12. Tripathy DN, Hanson LE and Mayrs WL (1970). Passive hemagglutination with fowl poxvirus. Avian Disease 14: 29-38. 